\title{
Perancangan Alat Uji Impak Charpy Sederhana Untuk Material Logam Baja St 30
}

\section{Design Of Simple Charpy Impact Test For Steel Meterial Steel Materials}

\author{
Dhilif Kumar $^{1)} *$ Amru Siregar ${ }^{2)}$, Dadan $\operatorname{Ramdan}^{2)}$, Zulfikar $^{2)}$ \\ 1) Alumni Prodi Mesin, Fakultas Teknik, Universitas Medan Area, Indonesia \\ 2) Prodi Mesin, Fakultas Teknik, Universitas Medan Area, Indonesia
}

\begin{abstract}
*Coresponding Email:
Abstrak

Perkembangan penelitian kekuatan bahan telah banyak dilakukan untuk mendapatkan karakteristik suatu bahan terhadap berbagai jenis beban yang diberikan sebelum dipergunakan pada suatu sistem permesinan.Kendala terbesar saat ini khususnya di wilayah Sumatera Utara ialah langkanya alat-alat uji kekuatan bahan. Oleh karena itu penelitian ini bertujuan untuk merancang alat uji kekuatan bahan akibat beban impak (tumbukan) dengan menggunakan bahan-bahan yang mudah diperoleh dan peralatan yang cukup sederhana. Penelitian ini juga diharapkan sebagai suatu usaha inovasi untuk memecahkan masalah kelangkaan alat uji kekuatan bahan untuk jenis-jenis beban uji lainnya. Metode pengujian impak yang dipergunakan dalam perancangan ini ialah jenis uji impak Charpy. Metode ini menggunakan teknik ayunan lengan untuk mendapatkan energi impak suatu bahan. Besarnya energi impak yang dihasilkan dihitung berdasarkan sudut ayunan yang dibentuk setelah proses pengimpakan. Panjang lengan bandul ialah $750 \mathrm{~mm}$ dengan berat bandul $15 \mathrm{~kg}$. Untuk mengukur sudut ayunan digunakan skala sudut bulat yang diletakkan tepat satu sumbu dengan sumbu ayunan. Hasilnya diperoleh alat uji impak ayunan bandul dengan spesifikasi seperti telah dijelaskan sebelumnya. Hasil uji coba mpak pada bahan baja ST 30 memperlihatkan energi impak pada bahan tersebut
\end{abstract}

Kata Kunci :Perancangan Alat Uji Impak, Metode Charpy, Baja ST 30.

\begin{abstract}
The development of research on the strength of materials has been done to obtain the characteristics of a material on various types of loads that are given before being used in a machining system. The biggest current constraint, especially in the region of North Sumatra is the scarcity of materials strength testing tools. Therefore, this study aims to design the material strength test equipment due to impact load (collision) by using materials that are easily obtained and the equipment is quite simple. This research is also expected as an innovation effort to solve the problem of scarcity of material strength test for other types of test load. The impact testing method used in this design is Charpy impact test type. This method uses a swing arm technique to obtain the impact energy of a material. The amount of impact energy generated is calculated based on the angle of swing formed after the overflow process. The length of the pendulum arm is $750 \mathrm{~mm}$ with a weight of $15 \mathrm{~kg}$. To measure the angle of swing is used round angle scale which is placed exactly one axis with the swing axis. The result obtained the impact test instrument swing pendulum with specifications as described previously. The result of mpak test on ST 30 steel material shows the impact energy on the material
\end{abstract}


Dhilif Kumar Amru Siregar, Dadan Ramdan, Zulfikar, Perancangan Alat Uji Impak Charpy Sederhana Untuk ...

How to Cite: Kumar, D. Amru, S. Dadan \& R. Zulfikar (2017). Perancangan Alat Uji Impak Charpy Sederhana Untuk Material Logam Baja St 30. JMEMME (Journal of Mechanical Engineering, Manufactures, Materials and Energy). 1 (1): 1-9 


\section{PENDAHULUAN}

Kebutuhan informasi karakteristik suatu bahan teknikbaik logam maupun non logam sangatlah pentingdalam perancangan teknik mesin. Bahan bajamerupakan bahan teknik yang masih mendominasi pemakaiannya dalam permesinan. Bahan ini banyak digunakan sebagai penguat rangka suatu konstruksi permesinan. Karakteristik sifat mekanik antar suatu bahan dengan bahan lainnya berbeda-beda. Sifat mekanik tersebut meliputi kekerasan, keuletan, kekuatan, ketangguhan, dan sifat mampu las. Sifat pada masing-masing material yang berbeda menyebabkan banyak metode pengujianuntuk mendapatkan sifat-sifat yang dimiliki oleh suatu material. Uji impak merupakan salah satu metode yang digunakkan untuk mengetahui kekuatan dan ketangguhan bahan akibat beban dengan laju kecepatan tinggi. Oleh karena itu uji impak banyak dipakai dalam bidang menguji sifat dinamik yang dimiliki oleh suatu material. Dalam pengujian tentu ada tahapan-tahapan yang perlu diperhatikan antara lain berupa besarnya sudut awal dan akhir, posisi material, dan suhu benda uji. Adapun harapan yang di inginkan dari pengujian ini ialah untuk menguji dan mengetahui kualitas bahan baja jenis ST 30.

$$
\text { Uji impak digunakan dalam }
$$
menentukan kecenderungan material untuk rapuh atau ulet akibat gerak benda berdasarkan sifat ketangguhannya[1]. Uji ini akan mendeteksi perbedaan yang tidak diperoleh dari pengujian tegangan regangan secara statik. Hasil uji impak juga tidak dapat membaca secara langsung kondisi perpatahan batang uji, sebab tidak dapat mengukur langsung komponen gaya-gaya tegangan tiga dimensi yang terjadi pada batang uji. Hasil yang diperoleh dari pengujian impak ini hanya berupa perubahan tinggi dan sudut akibat ayunan lengan bandul.

Uji impak merupakan suatu pengujian yang dilakukan untuk menguji ketangguhan suatu spesimen bila diberikan beban secara tiba-tiba melalui proses tumbukan. Ketangguhan adalah ukuran suatu energi yang diperlukan untuk mematahkan atau merusak suatu bahan yang diukur dari luas daerah dibawah kurva tegangan regangan. Suatu bahan mungkin memiliki kekuatan tarik yang tinggi tetapi tidak memenuhi syarat untuk kondisi pembebanan kejut. Suatu paduan memiliki parameter ketangguhan terhadap perpatahan yang didefinisikan sebagai kombinasi tegangan kritis dan panjang retak[2].

Sejumlah uji impak batang uji bertakik dengan berbagai desain telah dilakukan dalam menentukan perpatahan rapuh pada logam. Metode yang telah menjadi standar untuk uji impak ialah:uji impak metode Charpy dan metode Izod[3]. Metode charpy banyak digunakan di Amerika Serikat, sedangkan metode izod lebih sering digunakan di sebagian besar dataran Eropa. Batang uji metode charpy memiliki spesifikasi, luas penampang $10 \mathrm{~mm}$ x $10 \mathrm{~mm}$, takik berbentuk 
Dhilif Kumar Amru Siregar, Dadan Ramdan, Zulfikar, Perancangan Alat Uji Impak Charpy Sederhana Untuk ...

V. Proses pembebanan uji impak pada metode charpy dan metode izod dengan sudut 45, kedalaman takik $2 \mathrm{~mm}$ dengan radius pusat $0.25 \mathrm{~mm}$.

Pada pengujian metode Charpy, beban diayun dari ketinggian tertentu untuk memukul benda uji, yang kemudian diukur energi yang diserap oleh perpatahannya[1].Batang uji charpy kemudian diletakkan horizontal pada batang penumpu dan diberi beban secara tiba-tiba di belakang sisi takik oleh pendulum berat berayun (kecepatan pembebanan $\pm 5 \mathrm{~m} / \mathrm{s}$ ). Ilustrasi pengujian impak metode charpy diperlihatkan pada gambar 1.

\section{Enetgi pertotanes}

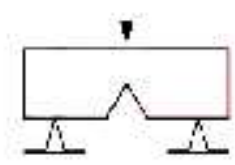

Gambar 1. Pengujian impak metode Charpy

Energi impak yang dihasilkan diperoleh berdasarkan perbedaan besarnya sudut $\Delta \alpha y a n g$ dibentuk pada saat sebelum dan sesudah pengimpakan. Energi sebelum pengimpakan dihitung dengan menggunakan persamaan 1[4].

$$
\mathrm{W}_{1}=\mathrm{m} \cdot \mathrm{L}(1-\cos \Delta \alpha)
$$

dimana: $\mathrm{W}=$ energi impak $(\mathrm{J}), \mathrm{m}=$ massa bandul $(\mathrm{kg}), \mathrm{L}=$ panjang lengan bandul $(\mathrm{m})$, dan $\Delta \alpha=$ perbedaan sudut ayunan bandul sebelum dan sesudah pengimpakan.

Adapun keunggulanuji impak metode charpy antara lain: 1) hasil pengujian lebih akurat, 2) pengerjaannya lebih mudah dipahami dan dilakukan, 3)menghasikan tegangan lebih seragam disepanjang penampang, 4) harga alat lebih murah, dan 5)waktu pengujian lebih singkat. Sementara kelemahan metode ini antara lain: 1) hanya dapat dipasang pada posisi horizontal, 2) Spesimen dapat bergeser dari tumpuannya karena tidak di cekam, 3)pengujian hanya dapat dilakukan pada specimen yang kecil, dan 4) hasil pengujian kurang dapat atau tepat dimanfaatkan dalam perancangan karena level tegangan yang diberikan tidak rata[5].

Tujuan penelitian ini ialah pembuatan alat uji impak berdasarkan metoda Charpy serta uji coba pengujian beban impak terhadap bahan baja ST 30 dengan variasi terhadap sudut takik pada spesimen uji $\left(30^{\circ}, 45^{\circ}\right.$, dan $\left.60^{\circ}\right)$ dan sudut awal impak $\left(30^{\circ}, 40^{\circ}, 50^{\circ}, 60^{\circ}\right.$, dan $70^{\circ}$ ). Sehingga diharapkan dapat dihasilkan alat uji impak bahan hasil rancang bangun sendiri.

\section{METODE PENELITIAN}

Penelitian ini dikerjakan di Laboratorium Teknik Mesin, Fakultas Teknik, Universitas Medan Area. Metode perancangan alat uji dalam penelitian ini adalah sebagai berikut: 1)perancangan tiang sebagai pondasi alat uji, pengukuran plat bentuk U dengan ukuran $250 \mathrm{~mm}$. 
Proses tersebut dikerjakan dengan menggunakan mesin gerinda potong, 2) memposisikan benda yang akan dipasang pada chasis(rangka), proses bor(melubangi) pada bagian yang akan disesuaikan dengan ukuran benda, 3) proses penyambungan dan penyatuan bagian-bagian alat uji, dan 4) pengukuran keseimbangan posisi tegak/berdiri alat uji dengan menggunakan waterpas. Selanjutnya posisikan benda atau komponen-komponen tersebut ke tempat dudukan yang telah ditentukan dan disesuaikan, serta ketatkan dengan pemasangan baut dan mur pengikat komponen dengan chasis(rangka).

Bagian - bagian dari alat uji impak yang dirancang dan dibangun ialah:

Skala ukur yang berfungsi untuk menunjukkan sudut pengayun sebelum dan sesudah dilepaskan hingga menabrak benda uji. Jarum penunjuk pada skala dihubungkan dengan poros pengayun yang diikat dengan baut sehingga arah ayunannya sesuai dengan arah poros pengayun.

bandul berfungsi sebagai beban yang ditabrakkan pada benda uji yang dilengkapi dengan pisau pemukul untuk mematahkan benda uji. Bagian atas pendulum ini dihubungkan ke bagian lengan pengayun dengan sambungan dilas.
Pisauimpak berfungsi untuk memukul benda uji, posisi pisau pada saat akan memukul berada dibelakang takikan benda uji.

Tuaspengangkat berfungsi untuk meneruskan gerakan ayunan dari poros ke pendulum. Bagian atas komponen ini dihubungkan ke poros dan pada bagian bawahnya dihubungkan ke pendulum dengan sambungan las.

Bantalan berfungsi untuk memperkokoh dudukan poros pada chasis. Bantalan yang digunakan berukuan diameter dalam $25 \mathrm{~mm}$. Bantalan ditempatkanpada bagian kanan dan kiri atas pada bagian alat uji impak dengan sambungan baut.

Roda gigi dan rantai berfungsi sebagai transmisi penggerak antara poros lengan bandul dan tuas pengangkat.

Poros berfungsi sebagai dudukan lengan bandul dan sebagai penerus ayunan dari bantalan ke lengan pengayun dan pendulum.

Dudukan berfungsi sebagai tempat dudukan benda uji. Tempat dudukan benda uji ini disambung las menyatu dengan badan alat uji impak.

Rangka/chasis berfungsi sebagai penyangga bandul dan lengan impak sehingga memiliki konstruksi yang lebih kokoh. 
Baut dan Mur berfungsi sebagai fungsinya untuk menghaluskan bagianpengikat komponen-komponen alat uji ke chasis. bagian yang ingin di cat.

Peralatan yang dipergunakan Untuk menguji kerja alat ini, maka selama penelitian ini adalah: Sarung tangan yang berfungsi sebagai pelindung tangan selama pekerjaan berlangsung, mesin gerinda tangan utuk memotong dan merapikan benda kerja, mesin gerinda potong fungsinya untuk memotong besi yang digunakan sebagai rangka dari alat uji impak, mesin las fungsinya utuk mengelas besi-besi agar menjadi suatu rangka alat uji impak yang kokoh, palu fungsinya untuk meluruskan dan merapikan apabila ada bagian yang membengkok, kunci ring pas fungsinya untuk megetatkan baut dan mur pada bagian alat uji impak, rol siku fungsinya untuk mengukur, alatukur panjang (meteran) fungsinya untuk mengkur panjang profil-profil besi yang digunakan untuk pembuatan alat uj impak, waterpas fungsinya untuk melihat kerataan rangka alat uji impak, ragum fungsinya untuk mengikat dan mempermudah ketika hendak ingin mengerjakan pada bagianbagian yang kecil, mesin bor fungsinya untuk melubangi bagian-bagian yang ingin diikat dengan baut dan mur, kacamata las fungsinya sebagai pelindung mata ketika ingin mengelas dan mengebor, amplas

\section{HASIL DAN PEMBAHASAN}

Bentuk alat uji impak charpy yang telah dirancang dan bangun diperlihatkan pada gambar 2. Alat ini memiliki ukuran keseluruhan sebagai berikut: tinggi $1,5 \mathrm{~m}$, panjang $1 \mathrm{~m}$, dan lebar $0,5 \mathrm{~m}$. Panjang lengan pengayun dari poros putaran ialah $750 \mathrm{~mm}$. 
Pada ujung lengan ayun terdapat bandul berukuran diameter $250 \mathrm{~mm}$ dan berat $15 \mathrm{~kg}$ yang berfungsi untuk membangkitkan energi impak pada spesimen uji. Bentuk bandul yang telah dibuat diperlihatkan pada gambar 3. Lengan ayun dihubungkan dengan poros penggerak yang terbuat dari bahan baja S45C berdiameter $15 \mathrm{~mm}$ dan panjang $200 \mathrm{~mm}$.

Bentuk spesimen uji impak metode charpy ini diperlihatkan pada gambar 4. Bentuk spesimen dibedakan atas sudut takik yang dibentuk. Pada penelitian ini sudut takik yang akan diuji ialah $30^{\circ}, 45^{\circ}$, dan $60^{\circ}$. Peletakan posisi benda uji terhadap bandulan diperlihatkan pada gambar 5. Hasil pengujian impak terhadap specimen-spesimen uji tersebut diperlihatkan pada gambar 6-8.

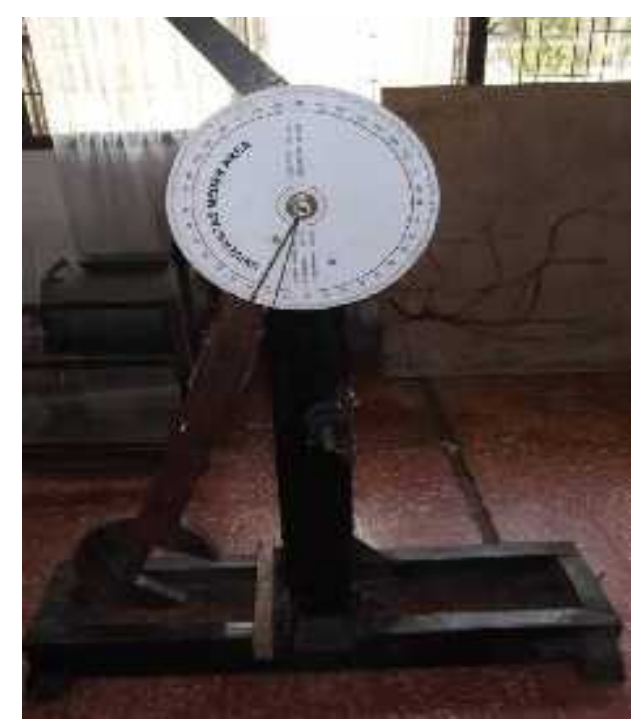

Gambar 2. Alat uji impak charpy

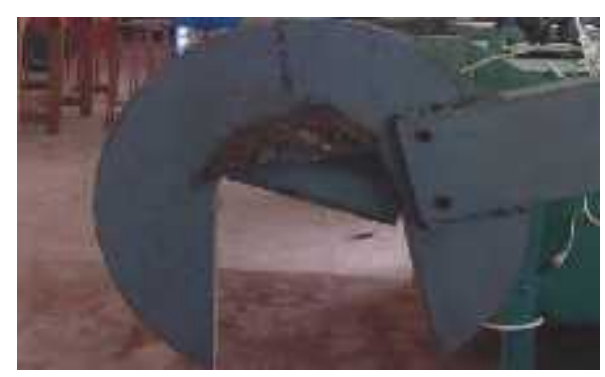

Gambar 3. Konstruksi bandul

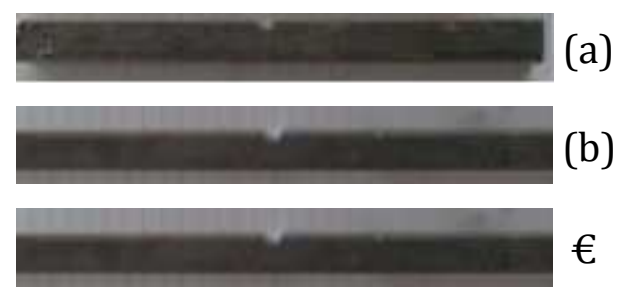

Gambar 4. Spesimen uji impak charpy bahan baja ST 30: (a) takik 30 ${ }^{\circ},(\mathrm{b}) \operatorname{takik} 45^{\circ}$, dan (c) takik 60

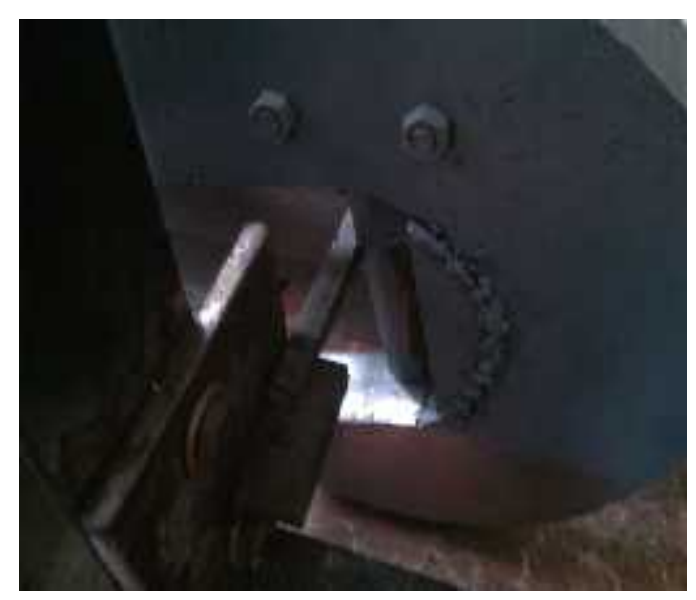

Gambar 5. Peletakan spesimen uji

(a)

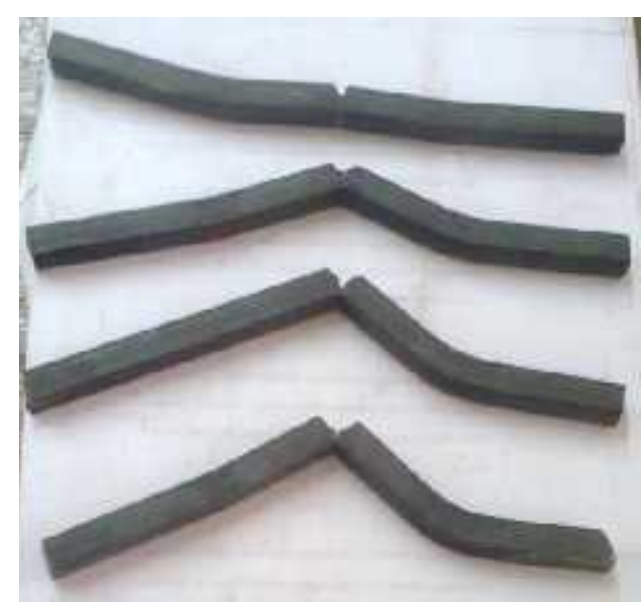

(d)

(e)

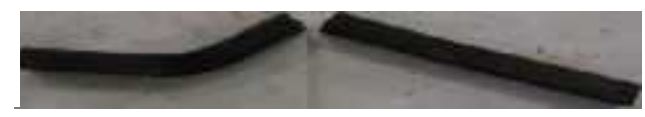

Gambar 6. Spesimen hasil uji impak dengan sudut takik $30^{\circ}$ : (a) sudut awal $30^{\circ}$, (b) sudut awal $40^{\circ}$, (c) sudut awal $50^{\circ}$, (d) sudut awal $60^{\circ}$, dan (e) sudut awal $70^{\circ}$ 
Dhilif Kumar Amru Siregar, Dadan Ramdan, Zulfikar, Perancangan Alat Uji Impak Charpy Sederhana Untuk ...

(a)

(b)

(c)

(d)

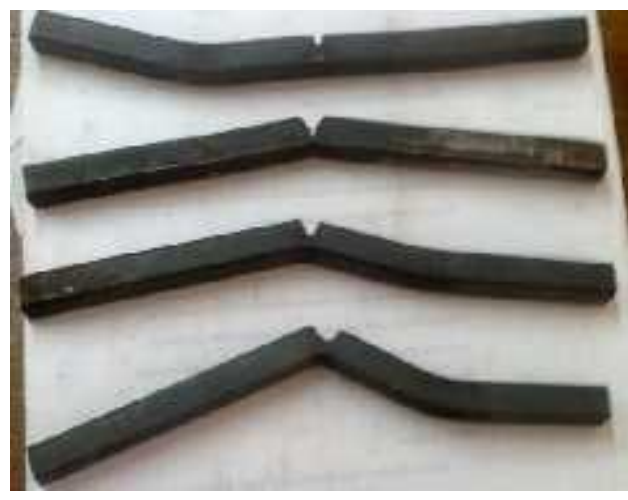

(e)

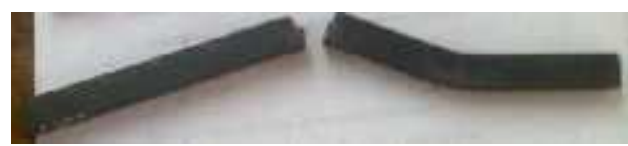

Gambar 7. Spesimen hasil uji impak dengan sudut takik $45^{\circ}$ : (a) sudut awal $30^{\circ}$, (b) sudut awal $40^{\circ}$, (c) sudut awal $50^{\circ}$, (d) sudut awal $60^{\circ}$, dan (e) sudut awal $70^{\circ}$
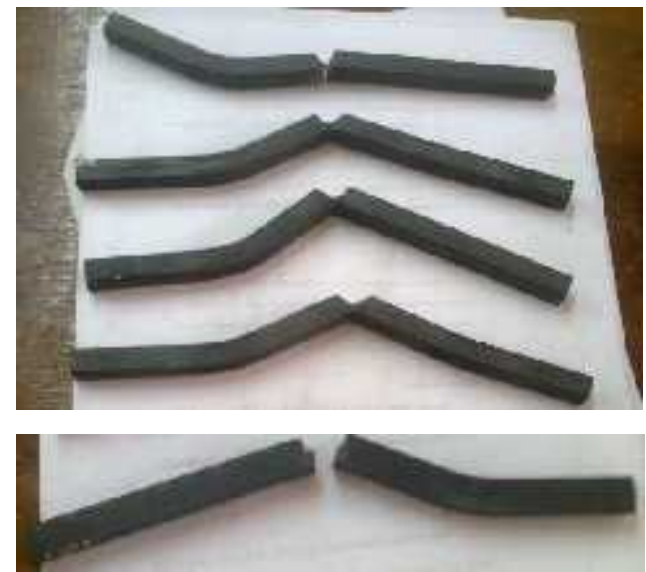

Gambar 8. Spesimen hasil uji impak dengan sudut takik $60^{\circ}$ : (a) sudut awal $30^{\circ}$, (b) sudut awal $40^{\circ}$,

(c) sudut awal $50^{\circ}$, (d) sudut awal $60^{\circ}$, dan (e) sudut awal $70^{\circ}$

Grafik hasil pengujian impak baja ST 30 pada masing-masing takik dan sudut awal diperlihatkan pada gambar 9.

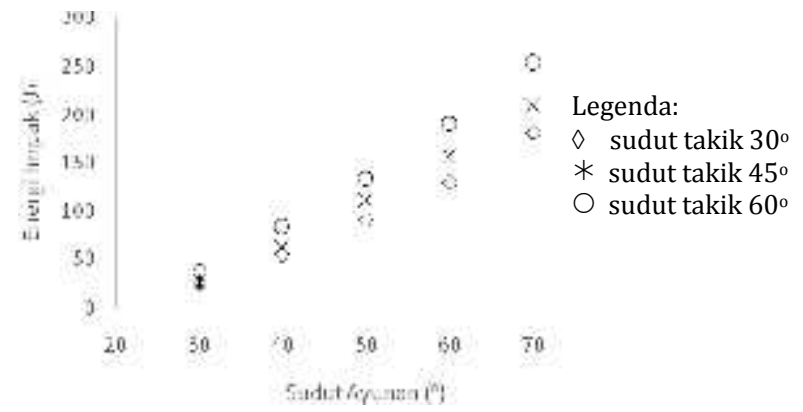

Gambar 9. Grafik energi impak (J) pada masingmasing sudut takik

Berdasarkan hasil pengujian tersebut, pada masing-masing sudut takik, semakin besar sudut impak yang dibentuk, maka akan semakin besar energi impak yang dihasilkan. Dengan demikian semakin mudah spesimen mengalami kerusakan dan patah. Efek pembesaran sudut takik berdasarkan pengujian dengan alat ini terlihat bahwa semakin besar sudut takik yang dibentuk pada spesimen uji, maka akan semakin besar juga energi impak yang dihasilkan. Hal ini berarti semakin mudah spesimen mengalami kerusakan/patah akibat semakin besarnya energi impak yang diterima spesimen. Pemberian retak awal akan mengakibatkan penurunan ketangguhan bahan akibat beban impak.

\section{SIMPULAN}

Berdasarkan hasil penelitian yang dikerjakan, yaitu mulai dari rancang bangun hingga uji coba pengujian beban impak terhadap spesimen bahan baja ST 30, dapat disimpulkan sebagai berikut : 
Alat uji impak berdasarkan metode impak Charpy telah berhasil dibangun dan diujicoba. Alat ini memiliki dimensi/ukuran: tinggi $1,5 \mathrm{~m}$, panjang $1 \mathrm{~m}$, dan lebar 0,5 $\mathrm{m}$. Panjang lengan pengayun dari poros putaran ialah $750 \mathrm{~mm}$. Pada ujung lengan ayun terdapat bandul berukuran diameter $250 \mathrm{~mm}$ dan berat $15 \mathrm{~kg}$ yang berfungsi untuk membangkitkan energi impak pada spesimen uji.

Hasil uji coba pengujian beban impak dengan menggunakan alat ini adalah sebagai berikut: semakin besar sudut impak yang dibentuk, maka akan semakin besar energi impak yang dihasilkan. Semakin besar sudut takik yang dibentuk pada spesimen uji, maka akan semakin besar juga energi impak yang dihasilkan. Hal ini menunjukkan bahwa alat uji telah bekerja dengan baik sesuai dengan teori impak yang berlaku.

\section{DAFTAR PUSTAKA}

[1] G. E. Dieter and L. C. Schmidt, Engineering Design, New York: McGraw-Hill, 2012.

[2] S. Zemasnky, Fisika untuk Universitas, Jakarta: Binacipta, 1995.

[3] J. E. Shigley, Mechanical Engineering Design, New York: Mc. Graw-Hill, 2006.

[4] L. H. Van Vleck, Ilmu dan Teknologi Bahan, Jakarta: Erlangga, 1989.

[5] J. M. Holt, Charpy Impact Test: Factors and Variables, Philadelphia: ASTM Publication, 1990. 